\title{
Effects of Nano-Carbon Reinforcement on the Swelling and Shrinkage Behaviour of Soil
}

(Kesan Pengukuhan Nanokarbon terhadap Sifat Pembengkakan dan Pengecutan Tanah)

\author{
Mohd Raihan Taha, Jamal M.A. AlshareF*, RAMEZ A. Al-Mansob \& TANVEer Ahmed Khan
}

\begin{abstract}
In this study, the performance of two types of nanocarbons (NCS), namely carbon nanotubes (CNTS) and carbon nanofibers (CNFs), on the three-dimensional shrinkage and swelling properties of three clayey soils were investigated. The specimens of soil mixed with clay with bentonite contents of 0,10 and $20 \%$ by weight of dry soil. NC contents of 0.05, 0.075, 0.10 and $0.20 \%$ were chosen to investigate the influence of different NC types, CNTs and CNFs. All soil specimens were compacted under maximum dry unit weight and optimum water content conditions by using standard compaction tests. The physical and mechanical characteristics of the reinforced samples were then determined. These included the desiccation cracking area, used to determine the crack intensity factor (CIF), as well as the shrinkage and swelling. The CIF for the soil specimens without NCs were higher than the soil specimens with NC additives. These results show that NCs decrease the development of desiccation cracks on the surface of compacted samples. The shrinkage and swelling tests showed that the rate of volume changing of the compacted soil specimens reduced with the increasing of NCs.
\end{abstract}

Keywords: Compaction; desiccation cracks; nano-fiber reinforcement; volume change

\section{ABSTRAK}

Dalam kajian ini, prestasi dua jenis nanokarbon (NC), iaitu tiub nano karbon (CNT) dan serat nano karbon (CNF) terhadap sifat pengecutan tiga dimensi dan sifat pembengkakan tiga jenis lempung dikaji. Spesimen tanah dicampur dengan lempung pada kandungan bentonit 0, 10 dan 20\% daripada berat tanah kering. Kandungan NC sebanyak 0.05 , 0.075, 0.10 dan 0.20\% dipilih untuk mengkaji pengaruh jenis NC yang berbeza iaitu CNT dan CNF. Semua spesimen tanah dipadatkan di bawah unit berat kering maksimum dan keadaan kandungan air yang optimum dengan menggunakan ujian pemadatan piawai. Ciri fizikal dan mekanik sampel tersebut ditentukan. Ini termasuk kawasan retak pengeringan yang digunakan untuk menentukan faktor keamatan retakan (CIF) serta pengecutan dan pembengkakan. CIF untuk spesimen tanah tanpa NC adalah lebih tinggi daripada spesimen tanah dengan bahan tambah NC. Keputusan ini menunjukkan bahawa NC mengurangkan pembentukan kesan retak pengeringan pada permukaan sampel yang dipadatkan. Ujian pengecutan dan pembengkakan menunjukkan bahawa perubahan kadar isi padu pada spesimen tanah yang dipadatkan dikurangkan dengan peningkatan NC.

Kata kunci: Pemadatan; pengukuhan nano-fiber; perubahan isi padu; retak pengeringan

\section{INTRODUCTION}

The changes in moisture content result in large volume changes in the fine soil. Swelling-shrinkage behavior, as well as desiccation cracks, are more apparent in soil near the ground surface because that is the medium directly impacted by seasonal and environmental changes (Nahlawi \& Kodikara 2006). To suppress this in the landfill linear area, the soil is normally compacted to reach maximum dry density $\left(\gamma_{d \max }\right)$ and optimum water content $\left(w_{o p t}\right)$ to reduce shrinkage strain after saturation (Albrecht \& Benson 2001). Accordingly, the long term performance of cover barrier systems regarding cracking of the compacted clay liners due to dryness is significant since the cracks in the compacted soil liner can severely decrease the sealing effect of the cover system (Witt \& Zeh 2005). Ige (2009) and Leroueil and Hight (2015) in studying the relationship between the hydraulic conductivity and volumetric shrinkage of compacted soil, concluded that for the construction of liners, volumetric shrinkage strain must be smaller than $11 \%$ to prevent noticeable increase in the hydraulic conductivity in soil. However, the changes in moisture of the soil can influence the internal stress equilibrium between the soil water and clay particles, and this mechanism of shrinking and swelling of fine soil is quite complex and can be influenced by several factors for example plasticity, climate, moisture content and clay content (Chen 1975; Houston et al. 2009).

Since the late 1980s, studies using polymeric fibers were conducted (Saran 2010). Furthermore, the use of synthetic fibers, such as polypropylene, polyamide and polyester fibers, in improving the mechanical properties and failure characteristics of soil have been confirmed (Diambra et al. 2010; Hataf \& Rahimi 2006; Kumar 
et al. 2006; Michalowski \& C C Ermák 2002; Park \& Tan 2005; Yetimoglu et al. 2005). Mixing soil with high tensile strength fibers results in fiber-reinforced soil with improved engineering properties.

In recent years, there has been an increase in interest in the use of fibers to suppress the problem of desiccation cracks. In this regard polypropylene fiber has become one of the most commonly used synthetic materials to reinforce concrete and soil (Hejazi et al. 2012; Plé\&Lê 2012). Its primary attractiveness is its low cost (Etter et al. 2011). Tang et al. (2007) reported that using fibers as additives can heighten the strength and ductility and reduce the stiffness of cement-stabilized clays. Moreover, Mirzababaei et al. (2013), in studying the effects of carpet waste fibers on the expansiveness of compacted clays, disclosed that as the percentage of fiber increased, the swelling pressure would decrease quickly. The interface between the fiber surface and the hydrated products (in fiber-reinforced cemented soil) has a noticeable impact on the strength of the interface. Nano-reinforcement

The development of nano-materials in soil reinforcement could result in considerable benefits as these materials have shown to give significant advantages, especially in concrete technology (Al-Mansob et al. 2017; Govindasamy et al.2017). Because of their unique mechanical properties carbon nanofibers (CNFs) and carbon nanotubes (CNTs) are gaining popularity as promising nanomaterials. The nanoscale and high aspect ratio of CNTs and CNFs imply that they can be dispensed on a much finer scale than the usually utilised micro-reinforced fibers (Alsharef et al. 2016; Nochaiya \& Chaipanich 2011; Taha $\&$ Alsharef 2017). Hence, microcracks can be intercepted faster during their proliferation in a nano-reinforced matrix. Thus, much smaller cracks are produced at the point of first contact between the moving crack front and the reinforcement. Widely researched in the last few decades, researchers originally investigated the usage of macro-to microfibers to control the formation of cracks in cementations materials such as concrete, cement paste and cement grout (Li et al. 2007; Mangat et al. 1984; Wang et al. 2008). Al-Rub et al. (2011) used scanning electron microscopy to analyze the microstructure of cementitious materials, both unreinforced and NCs reinforced and found that the nanofibers enhanced the mechanical properties of the cementitious material. Figure 1 shows the bridging of a nano-sized crack by CNTs and CNFs. The CNTs have a diameter of approximately $10 \mathrm{~nm}$, but they can bridge large cracks because of their high aspect ratio (Figure 1(a)). Figure 1(b) shows both treated CNFs and small needle-like ettringite formations, which could explain the degradation in mechanical properties observed with the acid-treated NCs.

Judging from the results seen in concrete, NCs may have potential to be excellent alternative to micro fibers as nano-reinforcement in high-performance soil. The effectiveness of NCs depends on two primary features; the distribution of NCs within the material and the bonding strength i.e. energy between NCs surface and the material

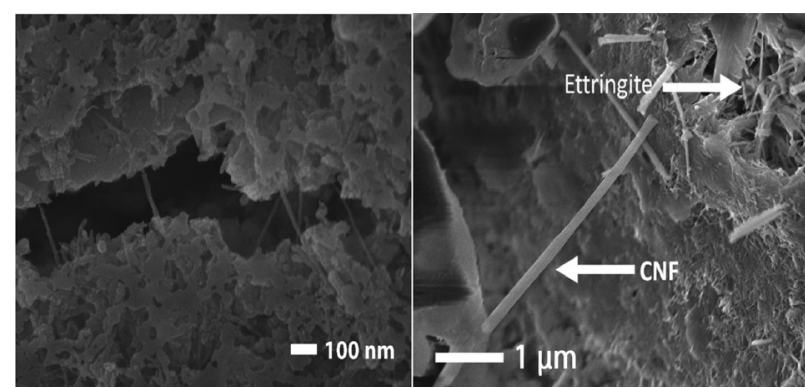

a) Untreated CNT embedded in cement paste bridging a nano-sized crack

b) $\mathrm{CNF}$ and ettringite formations

FIGURE 1. SEM image of different phases of cement shows the fracture surface of the sample containing untreated NCs, a) CNT and b) CNF (Al-Rub et al. 2011)

(Alsharef et al. 2017a; Nochaiya \& Chaipanich 2011). NCs are strongly drawn to each other due to their high van der Waals forces, Moreover, CNTs are more influenced by van der Waals forces than CNFs since their surface-tovolume ratio is higher. CNTs are more prone to bundling and agglomeration because of this higher attraction (Yazdanbakhsh et al. 2010).

\section{DISPERSION OF NANOCARBONS}

The problem of dispersing carbon nanoparticles in soil is one of the current critical hurdles that has hindered the widespread use of such materials in soil composites. The advantageous properties of CNFs and CNTs cannot be harnessed without controlling dispersion. A common method to improve CNFs and CNTs dispersion is by the use of surfactants. Dispersion of NCs in liquid media is a wellresearched topic and to accomplish this, many surfactants, combined with sonication, have been investigated (Alsharef et al. 2017b; Moore et al. 2003). However, most effective surfactants are not compatible with soil material (Taha et al. 2005) or cement hydration and their presence in cement paste usually results in a weak material in which significant quantity of air is entrapped. If not controlled properly, it can damage, shorten, or even dissolve the NCs material (Al-Rub et al. 2011; Yazdanbakhsh et al. 2010). Where surfactants prove to be inadequate in achieving dispersion in soil and concrete, ultrasonication has shown some promise. Ultrasonication can roughen the fiber surface thereby improving their bond with composites (Yazdanbakhsh et al. 2009). This bond strength is controllable and can even surpass a threshold value, which, if achieved, prevents fiber slippage. It is reported that the use of ultrasonication to effect considerable dispersion of nano-particles in aqueous solutions is frequently achieved. In particular, it has been shown that CNTs and CNFs can be effectively ultrasonically dispersed in a water solution (Cui 2013). Moreover, Firoozi et al. (2015) used ultrasonics for the dispersion of soil particles without pre-treating or adding a dispersing surfactant. The aim of this research was to investigate the performance of NCs additives on the 
compacted soil specimens. More specifically, the effect on NCs on the desiccation cracks (CIF), volumetric shrinkage behavior and liner shrinkage on compacted soil specimens is investigated. Scanning electron microscopy (SEM) and transmission electron microscopy (TEM) are utilized to examine the cracked surface of soil samples in order to understand how the NCs affects the mechanical properties of the soil specimens.

\section{MATERIALS AND METHODS}

\section{MATERIALS}

Residual soil from the vicinity of the National University of Malaysia, Bangi, was chosen for the study. The soil was sampled at depth of $1 \mathrm{~m} \pm 20 \mathrm{~cm}$ below the ground surface. The soil was mixed with different ratios of bentonite namely $\mathrm{S} 1=0 \%$ bentonite, $\mathrm{S} 2=10 \%$ and $\mathrm{S} 3=$ $20 \%$ bentonite to create three kinds of soil samples with different PI. The physical and chemical properties of each soil sample are listed in Table 1. The bentonite used in this study, for which properties are listed in Table 2, is a high sodium bentonite containing sodium montmorillonite.

The multi-walled CNTs, supplied by Arkema Inc. are produced under the trade name Graphistrength. Typical dimensions are $10-15 \mathrm{~nm}$ in diameter (5-15 walls) and 1-10 microns in length. The other nano-fiber material, PR-24-XT-LHT, a CNF from Pyrograf, was also used. The properties and other relevant information of the CNTs and CNFs, as provided by the companies, are shown in Tables 3 and 4, respectively. TEM images showing the shape of the NCs can be seen in Figure 2.

TABLE 1. Chemical and physical features of soil samples

\begin{tabular}{lccc}
\hline \multirow{2}{*}{ Characteristics } & \multicolumn{3}{c}{ Value and descriptions } \\
\cline { 2 - 4 } & $\mathrm{S} 1$ & $\mathrm{~S} 2$ & $\mathrm{~S} 3$ \\
\hline Specific gravity & 2.60 & 2.61 & 2.61 \\
Plasticity index (\%) & 13.6 & 31.4 & 64.5 \\
Liner shrinkage (\%) & 8.9 & 14.0 & 19.8 \\
Passing no 200 sieve (wt. \%) & 45.4 & 55.1 & 64.9 \\
Unified soil classification & $\mathrm{CL}$ & $\mathrm{CH}$ & $\mathrm{CH}$ \\
system (USCS) & & & \\
Optimum water content (\%) & 14.3 & 15.7 & 18 \\
Chemical composition & & & \\
$\mathrm{SiO}_{2}(\%)$ & 62.1 & 55.2 & 53.1 \\
$\mathrm{Al}_{2} \mathrm{O}_{3}(\%)$ & 29.5 & 21.3 & 23.5 \\
$\mathrm{Fe}_{2} \mathrm{O}_{3}(\%)$ & 5.7 & 5.2 & 5.2 \\
$\left.\mathrm{MgO}^{2} \%\right)$ & 0.58 & 1.5 & 1.1 \\
$\left.\mathrm{CaO}^{2} \%\right)$ & 0.03 & 1.23 & 1.0 \\
$\mathrm{TiO}_{2}(\%)$ & 1.17 & 0.9 & 0.9 \\
$\mathrm{Na}_{2} \mathrm{O}(\%)$ & -- & 1.2 & 0.8 \\
$\mathrm{~K}_{2} \mathrm{O}(\%)$ & 0.8 & 0.7 & 0.7 \\
$\mathrm{Other}^{\mathrm{Heat} \mathrm{loss}}$ & 0.1 & 0.4 & 0.3 \\
Organic matter $(\%)$ & 0.2 & 11.1 & 12.3 \\
\hline
\end{tabular}

TABLE 2. Bentonite properties

\begin{tabular}{ll}
\hline Property & Value \\
\hline Plastic limit & 70.0 \\
Liquid limit & 464.6 \\
Specific gravity & 2.65 \\
Cation exchange capacity & 90.0 meq $/ 00$ g of dry soil \\
Plasticity index & 394.3 \\
\hline Chemical composition & \\
\hline Formula & Concentration $(\%)$ \\
\hline $\mathrm{SiO}_{2}$ & 60.9 \\
$\mathrm{Al}_{2} \mathrm{O}_{3}$ & 14.8 \\
$\mathrm{Fe}_{2} \mathrm{O}_{3}$ & 4.4 \\
$\mathrm{CaO}$ & 3.7 \\
$\mathrm{Na}_{2} \mathrm{O}$ & 3.1 \\
$\mathrm{MgO}$ & 3.1 \\
$\mathrm{~K}_{2} \mathrm{O}$ & 0.8 \\
$\mathrm{TiO}_{2}$ & 0.6 \\
$\mathrm{Other}_{\mathrm{Heat}}$ & 0.4 \\
\hline
\end{tabular}

TABLE 3. Properties of CNT - (Graphistrength $\left.{ }^{\circledR} \mathrm{C} 100\right)$

\begin{tabular}{ll}
\hline Property & Value \\
\hline Average Diameter $(\mathrm{nm})$ & $10-15$ \\
Average length $(\mu \mathrm{m})$ & $1-10$ \\
Carbon purity $(\%)$ & $>95$ \\
Apparent density $\left(\mathrm{kg} / \mathrm{m}^{3}\right)$ & $50-150$ \\
Relative density $(\mathrm{g} / \mathrm{mL})$ at $25^{\circ} \mathrm{C}$ & 2,1 \\
Aspect ratio & $600-700$ \\
Applications & Reinforcements \\
\hline
\end{tabular}

TABLE 4. Properties of CNF -PR-19-XT-LHT

\begin{tabular}{ll}
\hline Property & Value \\
\hline Average diameter, $(\mathrm{nm})$ & 200 \\
Average length $(\mu \mathrm{m})$ & $50-200$ \\
Carbon purity $(\%)$ & $>98$ \\
Apparent density $\left(\mathrm{kg} / \mathrm{m}^{3}\right)$ & $30-300$ \\
CVD carbon overcoat present on fiber & No \\
Nanofiber wall Density, g/cc & $2-2.1$ \\
Iron, ppm & 12,466 \\
Aspect ratio & $1300-1500$ \\
Applications & Mechanical and \\
& electrical \\
\hline
\end{tabular}

\section{PREPARATION OF NANOCARBON-REINFORCED} SOIL MIXTURES

Sieve analyses and particle size distribution analyses based on the unified soil classification system, indicated that the soil is sandy with low plasticity clay index (CL). When the bentonite was added to the soil with dry weight percentages of $10 \%$ and $20 \%$, the soil is classified as high plasticity index clay $(\mathrm{CH})$. Sieve analyses for the three kinds of soil are displayed in Figure 4. 


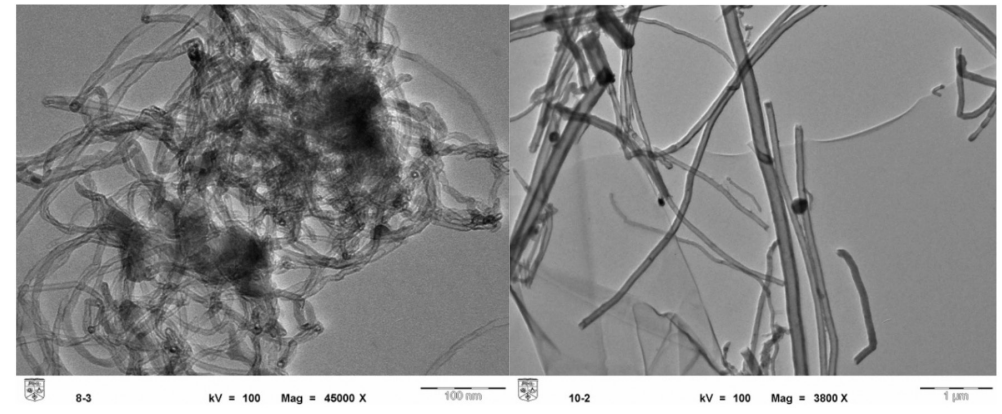

(a)

(b)

FIGURE 2. TEM micrograph showing shape of NCs: (a) CNT and (b) CNF

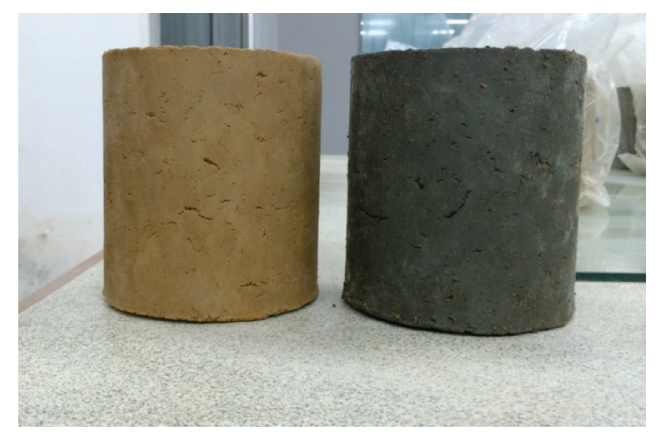

FIGURE 3. S3 Soil samples after compaction, the darker sample contains $0.2 \% \mathrm{CNF}$ while the lighter sample has no NC

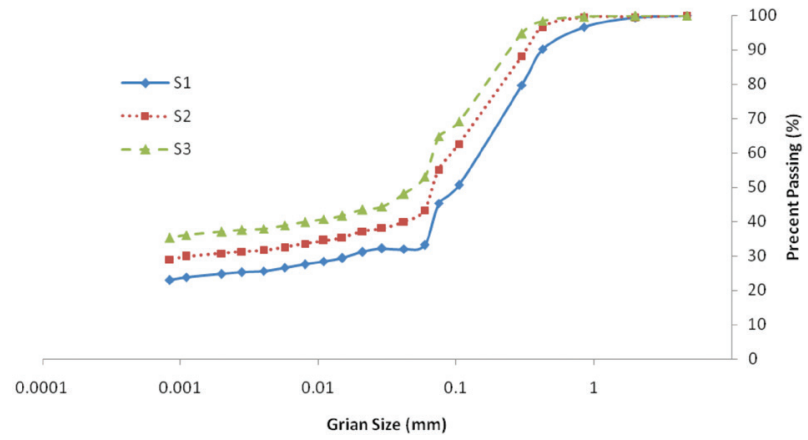

FIGURE 4. Grain size distribution for soil (S1) and soil with $10 \%(\mathrm{~S} 2)$ and $20 \%(\mathrm{~S} 3)$ bentonite

In further preparing the soil mixtures, the dispersion solution was then prepared by mixing $50 \mathrm{~g}$ of natural soil with $100 \mathrm{~mL}$ distilled water in a beaker. A soil-to-water mass ratio of 1:2 (by weight) was selected in order to assess the influence of water-filled volumes between soil particles on the movement of NCs. The quantity of NCs incorporated into the soil was $0 \%, 0.05 \%, 0.075 \%, 0.1 \%$ and $0.2 \%$ of the total dry weight of the soil. These NCs were first added to the water-soil solution and then manually mixed for 5 min. An ultrasonic tip was placed in the beaker and the mixture was sonicated for $4 \mathrm{~min}$ to disagglomerate the NCs while avoiding possible tube fragmentation (Vaisman et al. 2006). This time is also considered sufficient to accomplish dispersal of soil in the aqueous solution
(Firoozi et al. 2015), while preventing the suspensions from overheating (Lee et al. 2007). For the sonication process, the Sonic Ruptor 250 Ultrasonic Homogenizer was used. A piezoelectric ultrasonic transducer transforms a sinusoidal electrical voltage into a mechanical longitudinal resonance vibration with the resonance frequency of $20 \mathrm{kHz}$. The ultrasonic tip used has a cylindrical-shaped mediumintensity ultrasonic processor with a diameter of $19 \mathrm{~mm}$ and a length of $10.5 \mathrm{~cm}$. The device was operated at $50 \%$ of its maximum amplitude, delivering energy to the samples at a rate of 1900-2100 J/min. Energy was applied in cycles of $2 \mathrm{~s}$ to prevent the suspensions from overheating. Figure 5 shows the soil-water-NC suspension after sonication.

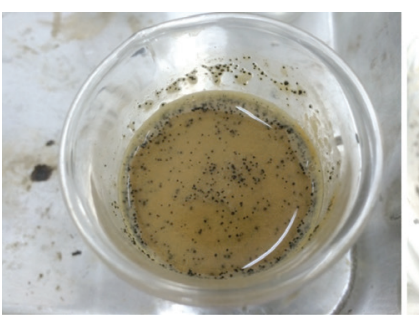

(a)

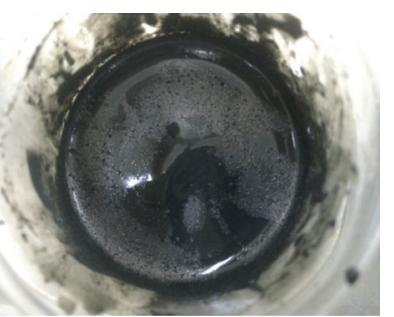

(b)
FIGURE 5. Effect of sonication on soil-water mixture:

(a) mixture after manually mixing, (b) suspension after 4 min of sonication

\section{SONICATION PROCESS}

The sonication process disperses both soil and NCs concurrently, resulting in a suspension. As the wide distribution of soil particles and NCs are dispersed, they overlap with each other while submicron clay particles act as wedges between the NCs and the larger soil particles. After sonication, the suspension was mixed thoroughly with the dry soil to achieve uniformity. This suspension incorporated with dry soil was then allowed to stand for $24 \mathrm{~h}$, as prescribed by ASTM D698-7, to allow water in the suspension to be thoroughly absorbed into the dry soil particles. From the homogeneous color observed after compaction, as shown in Figure 3, it can be concluded that this procedure resulted in materially homogeneous samples. 


\section{ATTERBERG LIMITS}

The Atterberg limits (i.e. the liquid limit, the plastic limit and the plasticity index) of each of the natural and treated soil samples were determined in accordance with BS 1377 , part 2, 1990. The liquid limit tests were performed using a penetration cone assembly, which consisted of a stainless steel cone with a cone angle of $30 \pm 1^{\circ} \mathrm{C}$. The plastic limit tests were performed using a manual method. Each sample was rolled at a sufficient pressure on a glass plate to form a thread with a uniform diameter of $3.2 \mathrm{~mm}$ along the full length of the sample. The plasticity index was calculated as the difference between the water contents at the liquid and plastic limits.

\section{MAXIMUM DRY DENSITY TEST}

The dry mixture was mixed with optimum moisture content (obtained through standard Proctor test) required to achieve maximum dry density for each NCs concentration. The standard Proctor compaction equipment was utilized to compact the soil samples at various water contents according to ASTM D698-70. The soil utilized for compaction was dehydrated in an oven and pounded with a rubber hammer and soil passing US No. 4 sieve was used for sample preparation. A spray bottle was used to dampen the soil with distilled water and stirred with a trowel while mixing to make sure there was an even distribution of water. Next, the soil was packed in plastic bags and allowed to saturate for minimum $24 \mathrm{~h}$ before compaction. Compacted specimens were utilized for expansive strain, shrinkage strain and desiccation crack tests. Volume change measurement was carried out to measure shrinking and expanding features. After compaction, the soil specimens were divided into two portions. The first portion was left to dry in an oven temperature $\sim 34 \pm 2{ }^{\circ} \mathrm{C}$ to measure shrinkage strain and the second portion was saturated with water to examine the expansion strain.

\section{VOLUMETRIC SHRINKAGE TEST}

Shrinkage occurred when wet soil dried up as threedimensional volumetric shrinking happened. Thus, the samples were dried from all sides according to ASTM C 157 after curing. The change in volume was used to establish the volumetric shrinkage strain of the soil samples. The volumetric shrinkage strain is noted as the change in volume $(\Delta \mathrm{V})$ to the total volume of the soil sample $\left(\mathrm{V}_{\mathrm{i}}\right)$, which is written as:-

$$
\text { Volumetric shrinkage strain }=\frac{\Delta V}{\mathrm{~V}_{i}} \times 100 \%
$$

\section{THREE-DIMENSIONAL FREE SWELL TEST}

This test recommended by National Lime Association (2004), in which larger specimens can be tested was chosen to determine the increase in volume due to capillary soaking. The change in volume was utilized to define the volumetric expansive strain of the soil samples. Similarly, the volumetric expansive strain is noted as the change in volume $(\Delta \mathrm{V})$ to the initial volume of the soil sample $\left(\mathrm{V}_{\mathrm{i}}\right)$, which is written as:-

$$
\text { Volumetric expansive strain }=\frac{\Delta V}{\mathrm{~V}_{i}} \times 100 \%
$$

\section{DESICCATION CRACK TEST}

In order to carry out desiccation crack test, soil samples were prepared at optimum water content using $152.4 \mathrm{~mm}$ (diameter) cylindrical mould with $116.43 \mathrm{~mm}$ in height. The drying process was carried out at a temperature of about $34 \pm 2^{\circ} \mathrm{C}$ for 10 days using an oven with fan. The surface dimensions of cracks were measured using gauge wires to find the crack intensity factor (CIF) to access the magnitude of desiccation cracks that form in the soils, which is written as (Harianto et al. 2008; Kleppe\&Olson 1985; Peng et al. 2006):

$$
C I F=\frac{A_{c}}{A_{t}}
$$

where $A_{c}$ is the desiccation crack area and $A_{t}$ is the total surface area of soil sample.

\section{RESULTS AND DISCUSSION}

The influence of bentonite on the specific gravity is shown in Table 1. The slight increase with the addition of bentonite is due to the fact that the specific gravity of bentonite is greater than that of the original soil. However, the increase in the plasticity index and liner shrinkage with the addition of bentonite is quite significant as shown in Figure 6. It is especially the increase in the plasticity index that resulted in the soil's classification being shifted to that of a highplasticity clay.

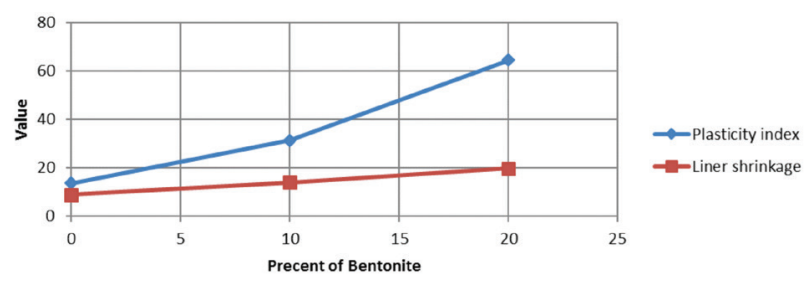

FIGURE 6. Effect of bentonite on liner shrinkage and plasticity index

\section{EFFECT OF CNTS AND CNFS ON PLASTICITY INDEX}

While the effect of the addition of CNTs to the plasticity index of the three soil specimens is insignificant, the effect of CNFs is significant in that more CNFs contribute to a decrease in the plasticity index (Figures $7 \& 8$ ). This behavior is likely due to the fact that CNFs have a higher 


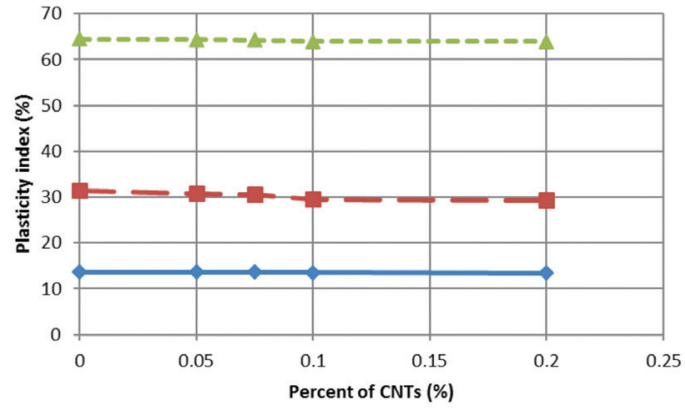

FIGURE 7. Effect of CNTs on plasticity index

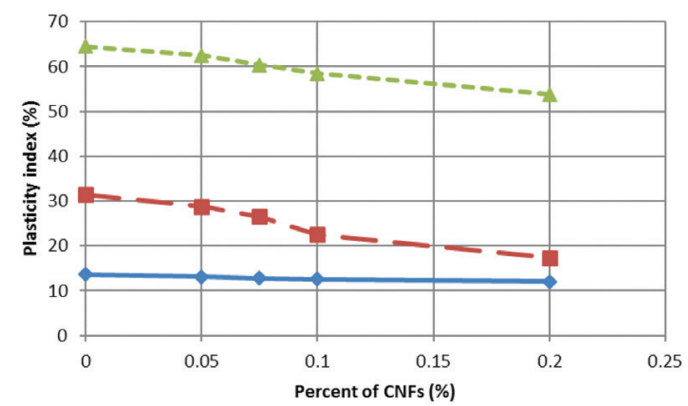

FIGURE 8. Effect of CNFs on plasticity index

aspect ratio than CNTs (Tyson et al. 2011). Generally, also, the NCs filaments have higher density than clay particles and their surface area is less than that of the bentonite particles. The CNFs however, are a super-hydrophobic and chemically inert material (Wang et al. 2008) and therefore does not soak up or respond to natural composite (soil moisture) or leachate as clay particles would.

\section{EFFECT OF NCS ON COMPACTION CONDITIONS}

There is a negligible effect of CNTs on the optimum water content $\left(w_{\mathrm{opt}}\right)$ for S2 and S3 soil specimens (Figure 9). However, some noticeable changes occurred for $\mathrm{S} 1$ soil ( $0 \%$ bentonite) with a decrease in $w_{\text {opt }}$ at $0.75 \% \mathrm{CNT}$ and an increase in $w_{\text {opt }}$ for higher CNTs. The change is mainly due to the displacement and rearrangement of soil particles induced by addition of CNTs and then filling soil voids, thereby reducing volume spaces in which water to be adsorbed. The work of Nochaiya and Chaipanich (2011) agrees with this in that they showed that the addition of CNTs was able to reduce the porosity. For specimens with CNFs, more significant changes occurred on $w_{\text {opt }}$ as the amount of CNFs increased (Figure 10). For the S3 soil ( $20 \%$ bentonite), there is a decrease in $w_{\text {opt }}$ up to $0.05 \%$ and constant $w_{\text {opt }}$ for higher levels of CNF.

Figures 11 and 12 show that adding NCs influence the maximum dry density $\left(\gamma_{d \max }\right)$ of the nano-reinforcement soil, in that $\gamma_{\text {dmax }}$ increased with increasing $\mathrm{NC}$, reaching a peak at $0.075 \%, 0.1 \%$ and $0.075 \%$ in $\mathrm{S} 1, \mathrm{~S} 2$, and $\mathrm{S} 3$ soil specimens, respectively, for CNT-reinforced soil specimens and peaking at $0.075 \%, 0.1 \%$ and $0.05 \%$ for the

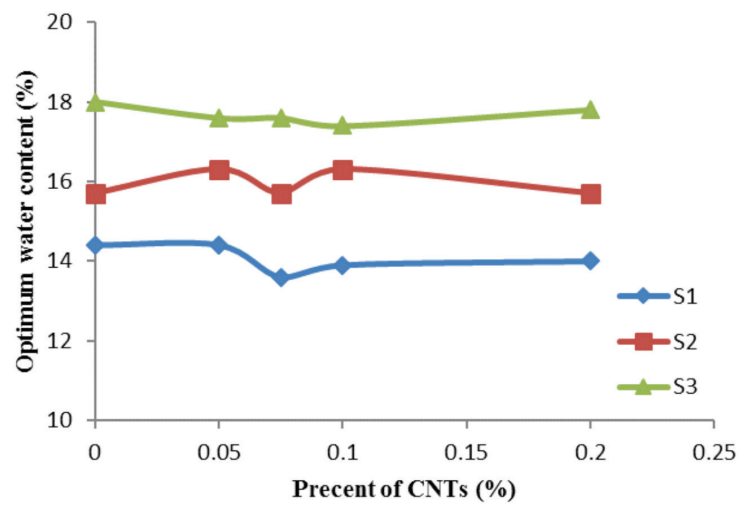

FIGURE 9. Effect of CNTs on $w_{\text {opt }}$

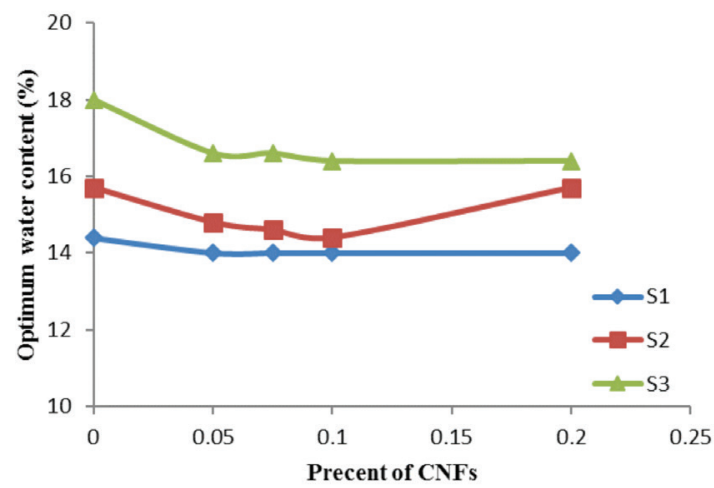

FIGURE 10. Effect of CNFs on $w_{\text {opt }}$

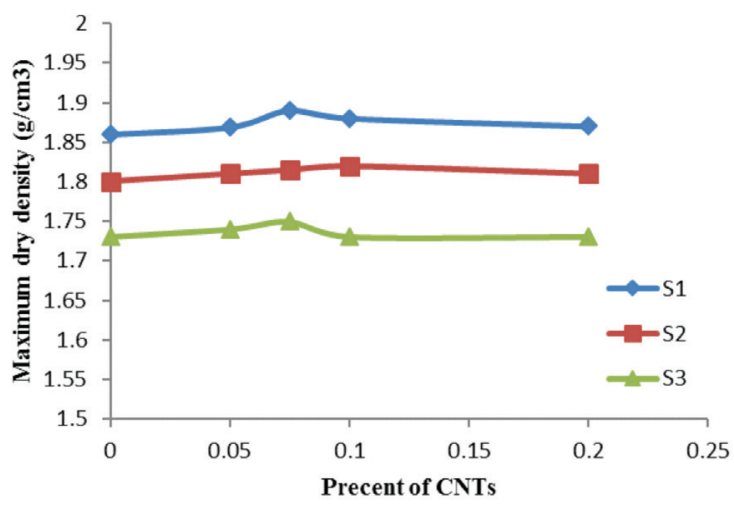

FIGURE 11. Effect of CNTs on $\gamma_{\mathrm{dmax}}$

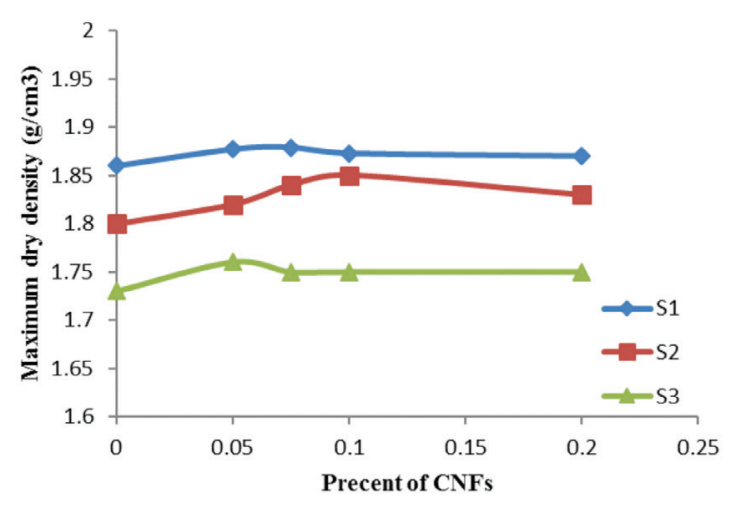

FIGURE 12. Effect of CNFs on $\gamma_{\mathrm{dmax}}$ 
respective CNF-reinforced soil specimens. It is apparent, however, that the effect of CNFs on $\gamma_{\mathrm{dmax}}$ is more significant compared to effect of CNTs. This is because the diameter and length of CNFs are greater than of CNTs (Blandine et al. 2016). Moreover, there is no increase in $\gamma_{\mathrm{dmax}}$ for NC contents above $0.10 \%$. However, it is observed that after the peak, increasing $\mathrm{NC}$ content results in a decrease in $\gamma_{d \max }$. It is expected that well-dispersed CNTs and CNFs would lead to filling of pores within soil with the fibers, thereby improving its microstructure. Example of such cases are shown in Figure 13. It is also possible, however, for fibers not to effectively fill the pore spaces or come in full contact with soil particles. In such cases, $\gamma_{\text {dmax }}$ would decrease (Harianto et al. 2008). It could be then that the inclusion of NCs beyond the optimum limit may possibly result from agglomeration of NC filaments. According to Ferkel and Hellmig (1999), increasing nano-material content beyond the optimum limit causes an increase in the void ratio thereby decreasing density and increasing water content. An example of the soil-mixture microstructure for such a case can be seen Figure 14. Such NC filament agglomeration was observed when the $\mathrm{NC}$ was incorporated at $0.2 \%$ and when the $\mathrm{NC}$ was mixed into the soil without sonication.

\section{EFFECT OF NCS ON SHRINKAGE AND EXPANSIVE STRAINS}

Figures 15 to 20 show the effect that increasing NC content causes on the different types of volumetric strains of the nano-reinforced soil specimens. In all cases, nano- reinforcement of the soil specimens results in a decrease in strain. This behavior can be explained as follows. Firstly, as the total contact area between the soil particles and NC filaments increases with increasing $\mathrm{NC}$ concentration, it provides more resistance, induced by soil-fiber interaction during the desiccation Cai et al. (2006). Secondly, less strain is attributed to the higher dry density and lower $w_{\text {opt }}$, when compared to soil specimens without nanoreinforcement. Figures 17 and 20 show the summation of the expansive and shrinkage strains, or the total strain of the soil samples. For all the soil specimens, it is noticeable that while strain decreases as NC content increases, the reduction in strain becomes insignificant as $\mathrm{NC}$ content surpasses $0.10 \%$. This is likely because the NCs filaments become more agglomerated at higher NC concentrations, which increases the void ratio and decreases the density. It is also observed that NCs are effective in reducing shrinkage and expansive strain of expansive soil specimens (such as S2 and S3) which experience large volume changes due to moisture content variations. Reduction in the volumetric shrinkage strain may be due to the increase in the strength of reinforcement in the soil, particularly the tensile strength as proposed by (Fatahi et al.2012). Other researchers have also found that the porosity and the total pore volume in reinforcement concrete decrease with the inclusion of CNTs (Siddique \& Mehta 2014). When reinforced with NCs, the lowering of pore volume in the soil leads to a denser microstructure, and thus lower shrinkage values compared to that of unreinforced soil.

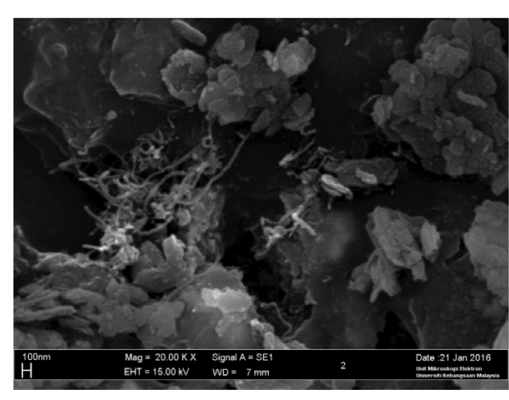

(a)

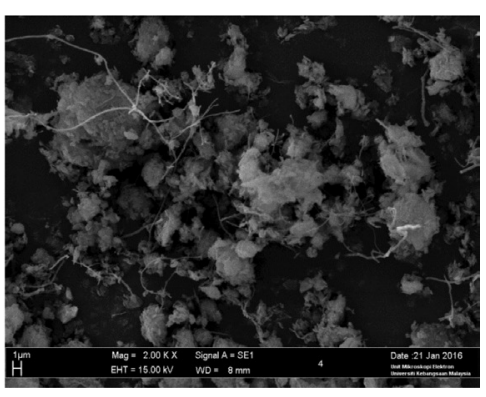

(b)

FIGURE 13. Distribution of NCs in soil after compaction: a) CNTs and b) CNFs

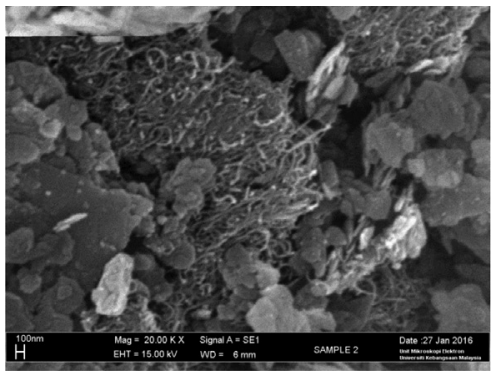

(a)

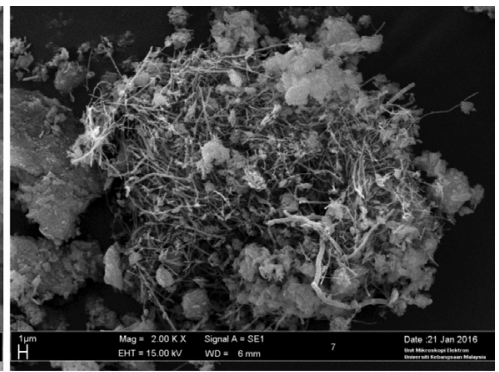

(b) 


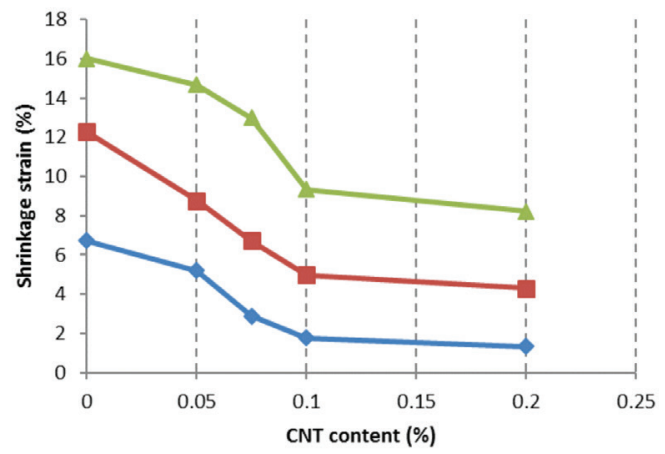

FIGURE 15. Effect of CNTs on shrinkage strain

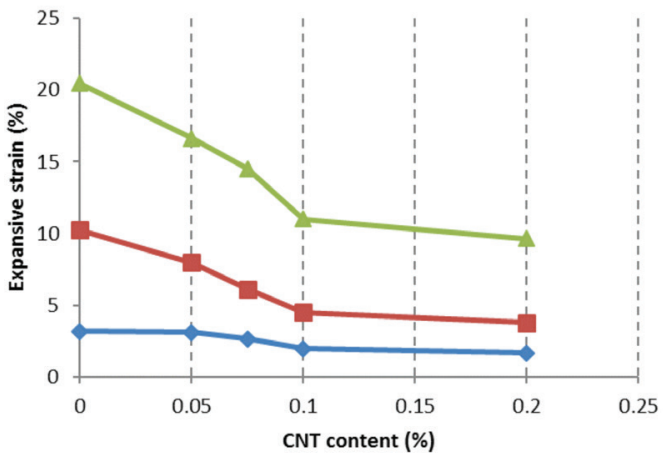

FIGURE 16. Effect of CNTs on expansive strain

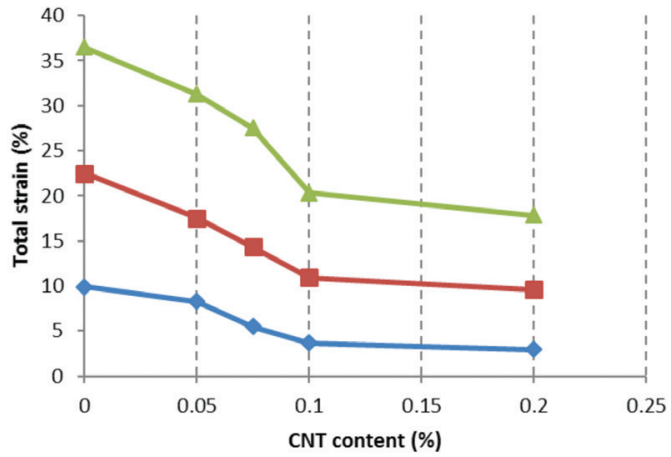

FIGURE 17. Effect of CNTs on total strain

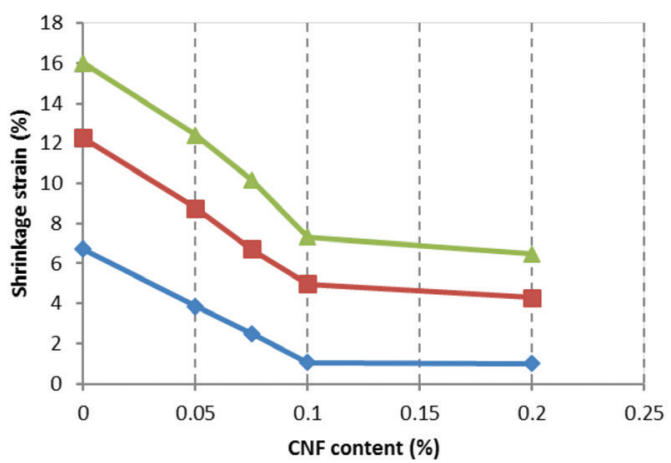

FIGURE 18. Effect of CNFs on shrinkage strain

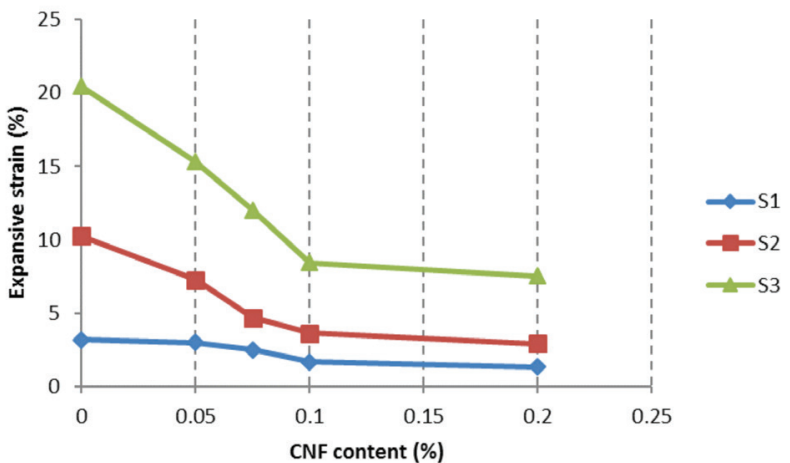

FIGURE 19. Effect of CNFs on expansive strain

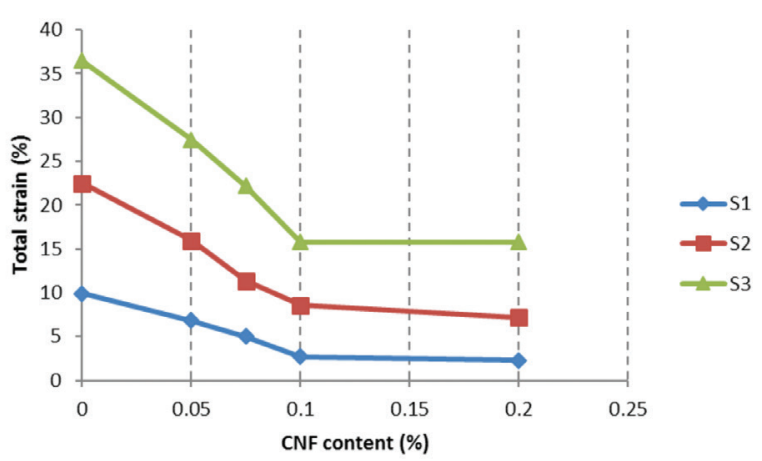

FIGURE 20. Effect of CNFs on total strain

Similar studies have found that the highest reduction of the volumetric shrinkage and expansive strain was observed for CNFs which were long, generally straight and had diameters of approximately $200 \mathrm{~nm}$ (Blandine et al. 2016). It is noticed that for bentonite modified soil specimens (S2 \& S3), the volumetric shrinkage strain was reduced by more than $11 \%$, making them suitable to be used as liners (Omidi et al. 1996a, 1996b). Figure 21 shows the schematic diagram (interpreted from Figures 13 and 22) of the mechanical behavior during the interface between NCs and soil particles. The NCs filament surface is interlocked and contacted with many soil particles causing a cumulative effect on the strength and friction between soil particles and NC filaments. Such mechanical behavior can enhance the impact of NCs to soil composite resistance namely interlock force, interfacial force and friction between the soil particles and NC filaments. However, it is worth noting that Cai et al. (2006) in their tests on the inclusion of fiber in clay stated that a rise in the fiber content can lead to a rise in shrinking potential of the chemically treated clay because of fiber slacking in the soil matrix during shrinkage.

\section{EFFECT OF NCS ON DESICCATION CRACKS}

The desiccation crack CIF for the sample without bentonite (S1) cannot be measured (low plasticity index), but the CIF for the other soil specimens (S2 and S3) are presented 


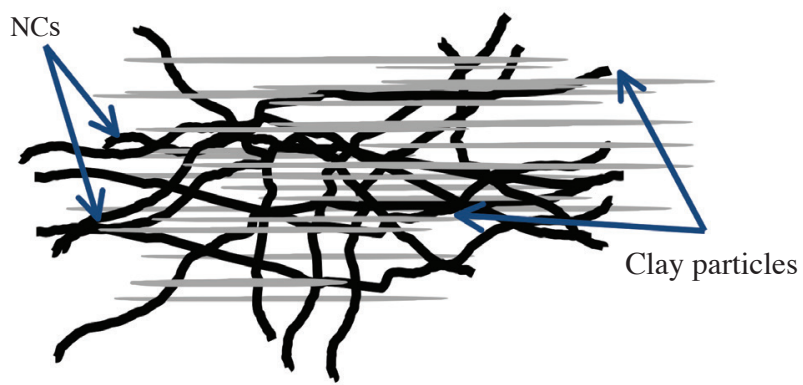

FIGURE 21. Schematic showing the progression of distribution of NCs in compacted soil after sonication

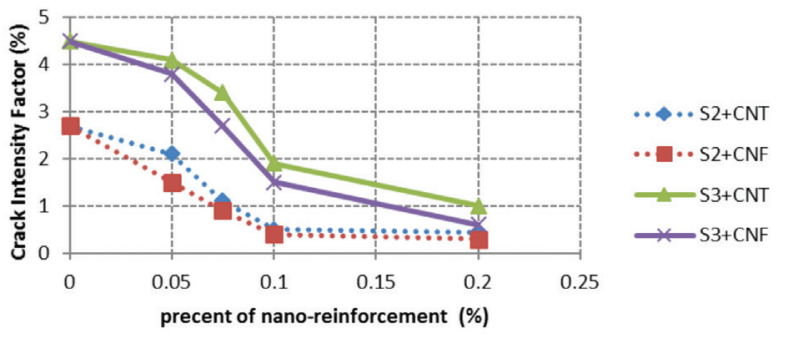

FIGURE 22. Effect of crack intensity factor (CIF) on the soil specimens at various NCs contents

in Figure 22. The maximum value of CIF was about $4.5 \%$ in $\mathrm{S} 3$ soil and this soil experienced a maximum reduction in CIF of $3.9 \%$ with CNF additives. Clearly, while the CIF of soil without NCs additives are significant, the addition of NCs results in a dramatic reduction in the CIF. The reduction in CIF when CNFS is used is slightly more than when CNTs is used. This is because the strain in soil with CNFs is less than the strain in soil with CNTs. Furthermore, as previously mentioned, with the addition of NCs, the friction between soil particles and NCs contributes to the development of resistance to the desiccation process. Whenever there is a tendency for the soil to shrink, it causes the soil-NCs resistance in soil to be activated, effectively suppressing cracks. When there is effective dispersion of CNs in compacted soil, it leads to the filling of pores, thereby improving its microstructure and restricting the propagation of nano-cracks and the formation of microand macro-cracks. An example of micro-crack bridging by the NCs within the soil, which leads to a reduction in CIF, is shown in Figure 23. Based on the magnification of the image, the CNFs, having diameters approximately 150 $\mathrm{nm}$, can be clearly seen .

\section{CONCLUSION}

The effect of NCs filaments reinforcement was positive in terms of expansive and shrinkage strain. This is conceivably due to diminutive dimensions of the nanomaterial and their high aspect ratios. These properties increase the specific gravity of the soil-NCs mixtures, thus, leading to an increase in the maximum dry density of the mixture. The increase in the dry density subsequently

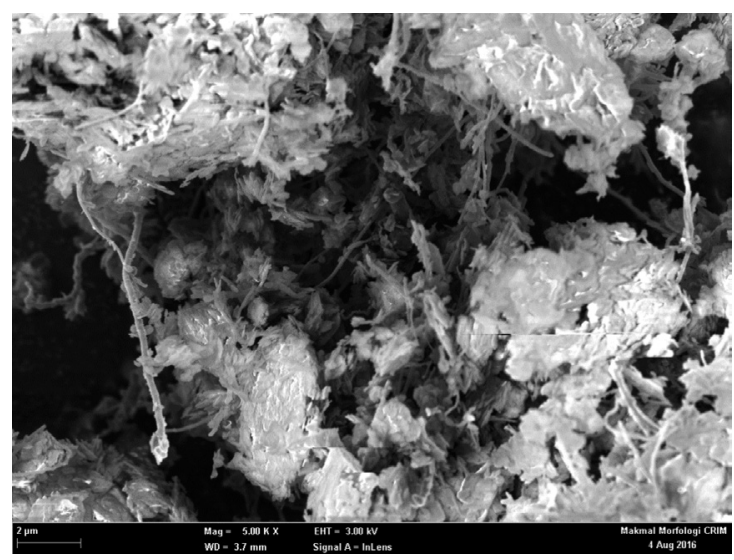

FIGURE 23. Micro-crack bridging by CNFs

results in decrease of soil shrinkage and expansive strains. Additionally, the cracks were significantly suppressed as demonstrated by a decrease in the CIF with increasing NCs content. This differs from other treatment materials like polypropylene and other types of fibre, which reduce cracks in the soil but increase the hydraulic conductivity, suggesting that NCs additives have potential application in soil as a possible procedure to overcome desiccation cracks commonly faced by landfill covered barriers. SEM images verified that there was good dispersion of NCs within the soil particles, confirming ultrasoniccation as a decent method of mixing.

This work emphasizes the need for further studies on the change in microstructural properties with nanoreinforcement in order to better understand how NCs improve soil strength properties.

\section{ACKNOWLEDGEMENTS}

The authors wish to acknowledge and appreciate the financial support and facilities provided by Geotechnical Engineering Lab of Universiti Kebangsaan Malaysia (UKM), as well as the Fuel Cell Institute for the conduction of FESEM and TEM test and the Ministry of Higher Education (MOHE), Malaysia through Universiti Kebangsaan Malaysia (UKM) via research project code DPP-2014-047.

\section{REFERENCES}

Al-Mansob, R.A., Ismail, A., Rahmat, R.a.O., Borhan, M.N., Alsharef, J.M., Albrka, S.I. \& Karim, M.R. 2017. The performance of epoxidised natural rubber modified asphalt using nano-alumina as additive. Construction and Building Materials 155: 680-687.

Al-Rub, R.K.A., Tyson, B.M., Yazdanbakhsh, A. \& Grasley, Z. 2011. Mechanical properties of nanocomposite cement incorporating surface-treated and untreated carbon nanotubes and carbon nanofibers. Journal of Nanomechanics and Micromechanics 2(1).

Albrecht, B.A. \& Benson, C.H. 2001. Effect of desiccation on compacted natural clays. Journal of Geotechnical and Geoenvironmental Engineering 127(1): 67-75. 
Alsharef, J.M., Taha, M.R., Al-Mansob, R.A. \& Khan, T.A. 2017a. Influence of carbon nanofibers on the shear strength and comparing cohesion of direct shear test and AFM. Journal of Nano Research 49: 108-126.

Alsharef, J.M., Taha, M.R. \& Khan, T.A. 2017b. Physical dispersion of nanocarbons in composites - A review. Jurnal Teknologi 79(5): 69-81.

Alsharef, J., Taha, M.R., Firoozi, A.A. \& Govindasamy, P. 2016. Potential of using nanocarbons to stabilize weak soils. Applied and Environmental Soil Science 2016: Article ID 5060531.

Blandine, F., Habermehi-Cwirzen, K. \& Cwirzen, A. 2016. Contribution of Cnts/Cnfs morphology to reduction of autogenous shrinkage of Portland cement paste. Frontiers of Structural and Civil Engineering 10(2): 224-235.

Cai, Y., Shi, B., Ng, C.W.W. \& Tang, C.S. 2006. Effect of polypropylene fibre and lime admixture on engineering properties of clayey soil. Engineering Geology 87(3-4): 230-240.

Chen, F.H. 1975. Foundations on Expansive Soils. Volume 12 of Development in Geotechnical Engineering. New York: Elsevier Scientific Publication Co.

Cui, L. 2013. Incorporation of multiwalled carbon nanotubes to ordinary Portland cement (OPC): Effects on mechanical properties. Advanced Materials Research 641-642: 436-439.

Diambra, A., Ibraim, E., Wood, D.M. \& Russell, A. 2010. Fibre reinforced sands: Experiments and modelling. Geotextiles and Geomembranes 28(3): 238-250.

Etter, B., Tilley, E., Khadka, R. \& Udert, K. 2011. Low-cost struvite production using source-separated urine in Nepal. Water Research 45(2): 852-862.

Fatahi, B., Khabbaz, H. \& Fatahi, B. 2012. Mechanical characteristics of soft clay treated with fibre and cement. Geosynthetics International 19(3): 252-262.

Ferkel, H. \& Hellmig, R. 1999. Effect of nanopowder deagglomeration on the densities of nanocrystalline ceramic green bodies and their sintering behaviour. Nanostructured Materials 11(5): 617-622.

Firoozi, A.A., Taha, M.R., Firoozi, A.A. \& Khan, T.A. 2015. Effect of ultrasonic treatment on clay microfabric evaluation by atomic force microscopy. Measurement 66: 244-252.

Govindasamy, P., Taha, M.R., Alsharef, J. \& Ramalingam, K. 2017. Influence of nanolime and curing period on unconfined compressive strength of soil. Applied and Environmental Soil Science 2017: Article ID 8307493.

Harianto, T., Hayashi, S., Du, Y.J. \& Suetsugu, D. 2008. Effects of fiber additives on the desiccation crack behavior of the compacted akaboku soil as a material for landfill cover barrier. Water, Air, and Soil Pollution 194(1-4): 141-149.

Hataf, N. \& Rahimi, M. 2006. Experimental investigation of bearing capacity of sand reinforced with randomly distributed tire shreds. Construction and Building Materials 20(10): 910-916.

Hejazi, S.M., Sheikhzadeh, M., Abtahi, S.M. \& Zadhoush, A. 2012. A simple review of soil reinforcement by using natural and synthetic fibers. Construction and Building Materials 30: 100-116.

Houston, S.L., Dye, H.B., Zapata, C.E., Walsh, K.D. \& Houston, W.N. 2009. Study of expansive soils and residential foundations on expansive soils in Arizona. Journal of Performance of Constructed Facilities 25(1): 31-44.

Ige, O.O. 2009. Assessment of geotechnical properties of migmatite-derived residual soil from Ilorin, Southwestern
Nigeria, as barrier in sanitary landfill. Continental Journal of Earth Sciences 4: 23-33.

Kleppe, J.H. \& Olson, R.E. 1985. Desiccation cracking of soil barriers. In Hydraulic Barriers in Soil and Rock: A Symposium edited by Johnson, A.I., ASTM Committee D-18 on Soil and Rock (USA); United States Committee on Large Dams. Italy: ASTM International.

Kumar, A., Walia, B.S. \& Mohan, J. 2006. Compressive strength of fiber reinforced highly compressible clay. Construction and Building Materials 20(10): 1063-1068.

Lee, J., Kim, M., Hong, C.K. \& Shim, S.E. 2007. Measurement of the dispersion stability of pristine and surface-modified multiwalled carbon nanotubes in various nonpolar and polar solvents. Measurement Science and Technology 18(12): 3707-3712.

Leroueil, S. \& Hight, D. 2015. Compacted soils: From physics to hydraulic and mechanical behaviour. Proceedings of the 1st Pan-American Conference on Unsaturated Soils (PanAmUNSAT'13). hlm. 41-59.

Li, G.Y., Wang, P.M. \& Zhao, X. 2007. Pressure-sensitive properties and microstructure of carbon nanotube reinforced cement composites. Cement and Concrete Composites 29(5): 377-382.

Mangat, P., Motamedi-Azari, M. \& Ramat, B.S. 1984. Steel fibrecement matrix interfacial bond characteristics under flexure. International Journal of Cement Composites and Lightweight Concrete 6(1): 29-37.

Michalowski, R.L. \& C Ermák, J. 2002. Strength anisotropy of fiber-reinforced sand. Computers and Geotechnics 29(4): 279-299.

Mirzababaei, M., Miraftab, M., Mohamed, M. \& Mcmahon, P. 2013. Impact of carpet waste fibre addition on swelling properties of compacted clays. Geotechnical and Geological Engineering 31(1): 173-182.

Moore, V.C., Strano, M.S., Haroz, E.H., Hauge, R.H., Smalley, R.E., Schmidt, J. \& Talmon, Y. 2003. Individually suspended single-walled carbon nanotubes in various surfactants. Nano Letters 3(10): 1379-1382.

Nahlawi, H. \& Kodikara, J. 2006. Laboratory experiments on desiccation cracking of thin soil layers. Geotechnical \& Geological Engineering 24(6): 1641-1664.

Nochaiya, T. \& Chaipanich, A. 2011. Behavior of multi-walled carbon nanotubes on the porosity and microstructure of cement-based materials. Applied Surface Science 257(6): 1941-1945.

Omidi, G., Prasad, T., Thomas, J. \& Brown, K. 1996a. The Influence of amendments on the volumetric shrinkage and integrity of compacted clay soils used in landfill liners. Water, Air, and Soil Pollution 86(1-4): 263-274.

Omidi, G., Thomas, J. \& Brown, K. 1996b. Effect of desiccation cracking on the hydraulic conductivity of a compacted clay liner. Water, Air, and Soil Pollution 89(1-2): 91-103.

Park, T. \& Tan, S.A. 2005. Enhanced performance of reinforced soil walls by the inclusion of short fiber. Geotextiles and Geomembranes 23(4): 348-361.

Peng, X., Horn, R., Peth, S. \& Smucker, A. 2006. Quantification of soil shrinkage in 2D by digital image processing of soil surface. Soil and Tillage Research 91(1): 173-180.

Plé, O.\& Lê,T. 2012. Effect of polypropylene fiber-reinforcement on the mechanical behavior of silty clay. Geotextiles and Geomembranes 32: 111-116.

Saran, S. 2010. Reinforced Soil and Its Engineering Applications. IK International Pvt Ltd. 
Siddique, R. \& Mehta, A. 2014. Effect of carbon nanotubes on properties of cement mortars. Construction and Building Materials 50: 116-129.

Taha, M.R. \& Alsharef, J.M.A. 2017. Use of nanocarbons to control wwelling, shrinkage, and hydraulic conductivity of a residual soil. Proceedings of the 2nd Symposium on Coupled Phenomena in Environmental Geotechnics (CPEG2), Leeds, UK 2017.

Taha, M.R., Ismail, E., Chik, Z., De Miguel, Y., Porro, A. \& Bartos, P. 2005. Some nano aspects and concepts in geotechnology. 2nd Int. Symp. on Nanotechnology in Construction, Bilbao, Spain. hlm. 373-381.

Tang, C., Shi, B., Gao, W., Chen, F. \& Cai, Y. 2007. Strength and mechanical behavior of short polypropylene fiber reinforced and cement stabilized clayey soil. Geotextiles and Geomembranes 25(3): 194-202.

Tyson, B.M.,Abu Al-Rub, R.K., Yazdanbakhsh,A.\& Grasley,Z. 2011. Carbon nanotubes and carbon nanofibers for enhancing the mechanical properties of nanocomposite cementitious materials. Journal of Materials in Civil Engineering 23(7): 1028-1035.

Vaisman, L., Marom, G. \& Wagner, H.D. 2006. Dispersions of surface-modified carbon nanotubes in water-soluble and water-insoluble polymers. Advanced Functional Materials 16(3): 357-363.

Wang, C., Li, K.Z., Li, H.J., Jiao, G.S., Lu, J. \& Hou, D.S. 2008. Effect of carbon fiber dispersion on the mechanical properties of carbon fiber-reinforced cement-based composites. Materials Science and Engineering: A 487(1): 52-57.

Witt, K. \& Zeh, R. 2005. Cracks due to desiccation in cover lining systems phenomena and design strategy. International Workshop LIRIGM, Grenoble University, France.

Yazdanbakhsh, A., Grasley, Z., Tyson, B. \& Abu Al-Rub, R. 2010. Distribution of carbon nanofibers and nanotubes in cementitious composites. Transportation Research Record: Journal of the Transportation Research Board 2142: 89-95.
Yazdanbakhsh, A., Grasley, Z., Tyson, B. \& Al-Rub, R.A. 2009 Carbon nano filaments in cementitious materials: Some issues on dispersion and interfacial bond. ACI Special Publication 267: 21-34.

Yetimoglu, T., Inanir, M. \& Esatinanir, O. 2005. A study on bearing capacity of randomly distributed fiber-reinforced sand fills overlying soft clay. Geotextiles and Geomembranes 23(2): 174-183.

Jamal M.A.Alsharef*, Mohd Raihan Taha, Ramez A.Al-Mansob \& Tanveer Ahmed Khan

Department of Civil and Structural Engineering

Universiti Kebangsaan Malaysia

43600 UKM Bangi, Selangor Darul Ehsan

Malaysia

Mohd Raihan Taha

Institute for Environment and Development (LESTARI)

Universiti Kebangsaan Malaysia

43600 UKM Bangi, Selangor Darul Ehsan

Malaysia

*Corresponding author; email: jamalshref@yahoo.com

Received: 8 March 2017

Accepted: 21 June 2017 